821.163.41.08-1 Богдановић П. https://doi.org/10.18485/sj.2017.22.1.4

МИЛОШ М. КОВАЧЕВИТ *

Филолошки факултет Београд

Филолошко-уметнички факултет Крагујевац
Оригинални научни рад

Примљен: 18. 09. 2016.

Прихваћен: 15. 12. 2016.

\title{
СТИЛИСТИКОМ КРОЗ ПЈЕСМУ О КЬИЗИ СВИЈЕТА ПРЕДРАГА БОГДАНОВИЋА ЦИЈА
}

У раду ${ }^{1}$ се даје потпуна лингвостилистичка анализа пјесме „И видех књигу” Предрага Богдановића Ција. Наведена пјесма на најбољи начин показује како је и зашто је „књига” основна тема пјесништва Богдановићевог. Анализа подразумијева освјетљење кохезивне и кохеренцијске структуре ове Богдановићеве пјесме, и проводи се с обзиром на кохезивно-кохеренцијско структурисање строфа понаособно и у њиховом међуодносу. Анализа показује структурну истовјетност свих сем посљедње, завршне строфе, што је условљено садржајним карактером књига што их пјесник види „како/које лете”, с којим се усаглашава и (не)емоционални начин опјевавања књига као еквивалента иманентних дијелова свијета и животу у њему.

Кључне ријечи: Предраг Богдановић Ци, књига, хармонија свијета, хармонија пјесме, паралелизам, кохезија, кохеренција

Предраг Богдановић Ци у српској се књижевности појавио као пјесник седамдесетих година прошлога вијека. И остао вјеран поезији. Објавио је седам збирки поезије: Доле, доле где ракови живе (Београд: Видици, 1970), Кроз кишу је Еским са рибама освојио небо (Београд: ИЦС, 1972), Бам Челик и чардак на

"mkovacevic31@gmail.com

${ }^{1}$ Рад је урађен у оквиру пројекта 178014: Динамика структура савременог српског језика, који у оквиру основних истраживања финансира Министарство просвете, науке и технолошког развоја Републике Србије. 
четири воде (Београд: ИЦС, 1978), Скомрах женик леђанске невесте (Београд: Нова књига, 1985), Александријска библиотека (Београд: БИГЗ, 1994), Ходећи водом (Београд: Просвета, 1997), и Трубе и печати (Београд: Рашка школа, 2010). Критичари се слажу да је између наведених седам збирки умјетнички најуспјешнија посљедња, на којој је очигледно пјесник и најдуже радио, јер је од појављивања претпосљедње дијели пуних тринаест година. Међутим, иако је својим изласком временски толико удаљена од претходних, посљедња се збирка тематски потпуно наслања на претходне двије пјесникове збирке будући да је у све трима њима КЊИГА основни Богдановићев пјеснички мотив. На то експлицитно указује М. Радовић, тврдњом да је пјеснички задатак „како да Књига постане извориште песништва” Предраг Богдановић Ци „песнички решавао у збирци песама Трубе и печати, а пре тога у значајној збирци Александријска библиотека (1994) и касније Ходећи водом (1997) - збиркама које чине својеврстан лирски триптихон". (Радовић 2010: 119-120). А у том триптихону Ци је у пјесничком виђењу књиге потпуно обрнуо перспективу „жреца симболизма, Стефана Малармеа”, који је сљедећом крилатицом „одредио сврху постојања света односом према књизи: 'Свет постоји да би једнога дана постао Лепом Књигом!' [...] И свет поезије постоји само зато да би довео до рађања Књиге. За Предрага Богдановића - Ција задатак песника је постављен не у духу Малармеовског обрта. Реч је сада о једном преобрату: не више о томе како да песме дорасту до књиге и постану од књиге песама књигом света, већ се ради о нечему сасвим другом: како да Књига постане извориште песништва?" (Радовић 2010: 119).

И Слободан Ракитић сматра да је „појам књиге” у Богдановићевој збирци Трубе и печати „супститут за свет”, „сам живот, подједнако видљив и невидљив, очигледан и тајанствен”. Заправо, „замисао Богдановићева је да обухвати целину света у свој различитости, сложености и дисперзији. Трагајући за том књигом над књигама Богдановић је у ствари трагао за суштином људског постојања, али и за смислом песничке уметности" (Ракитић 2010:17). Најексплицитнију потврду томе Ракитић проналази „у првој песми првог циклуса ('И видех књигу')", гдје се „говори о књизи која је 'чувар речи', односно 'чувар живота'. Можда и чувар света. Или је она сама собом свет јер садржи све птице, инсекте, гласове, звуке таласа и грања, речи сликара, писца и истраживача, али и мена убица, силника сањара рата. Зато Богдановић, набрајајући њена својства, такву крилату књигу уздиже до симбола, указујући да је њен стварни наслов (односно име) 'чувар речи', 'хармонија васионе', истина, али и 'неистина' и 'невера'. Најзад, име те књиге, која симболизује тоталитет живота, јесте и 'заборав историје, младости, скок срца у ништавило"”. (Ракитић 2010: 13).

Уводна пролошка пјесма „И видех књигу” у збирци Трубе и печати из више разлога је најкарактеристичнија пјесма између свих, а многобројних, 
Богдановићевих пјесама посвећених „појму књиге” као слици свијета и живота уопште. Она је најопштија Богдановићева пјесма о књизи. Она је и најексплицитнија Богдановићева пјесма о књизи, она је - посматрана из аспекта кохезивности и кохерентности - готово уникатна у Богдановићевом стваралаштву. И уза све то она је својеврсна „катафоричка” пјесма, чије се идеје разрађују, односно конкретизују у осталим Богдановићевим пјесмама о књигама друкчије тематике што их доноси Богдановићев пјеснички триптихон о књизи, а посебно и најнаглашеније збирка Трубе и печати, чији је саставни дио и на чијем је почетку у функцији „поетичке уводнице” смјештена.

Но, прије преласка на лингвостилистичку анализу, будући да ће та анализа укључивати сваки стих, неопходно је пјесму „И видех књигу” навести у цјелини:

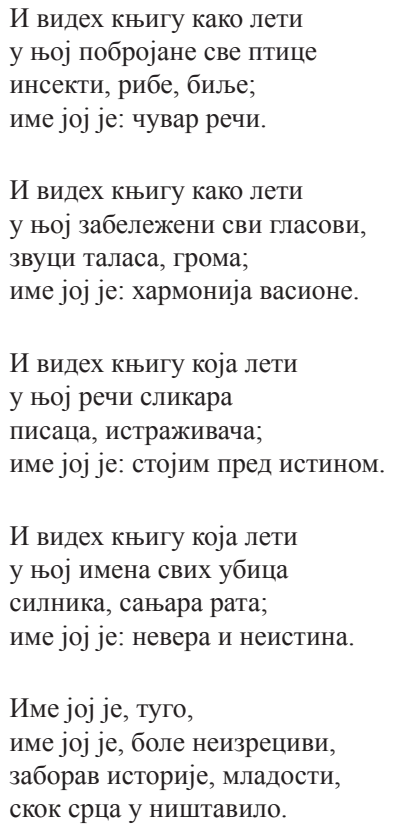

Пјесма је изострофична, састављена је од пет структурно истовјетних - катренских - строфа. Међутим, њена структура није изосилабична, јер је чине седмоврсни и бројем употреба неподударни метрички мјешовити стихови: шестерац (један), седмерци (три), осмерци (четири) деветерци (шест), десетерци (два), једанаестерци (два) и дванаестерци (два). Заступљене су, дакле, све метричке форме стихова од шестерца до дванаестерца, с тим што је највише деветераца (шест), при чему се чак три метричка типа реализују по два пута, док је јединачно остварен само шестерачки стих. Таква бројчана дистрибуција метричких типова стихова никако није случајна, она је прије 
свега условљена њиховом позиционом дистрибуцијом, и статусом датих стихова у кохезионој и кохеренцијској структури како појединих строфа тако и пјесме у цјелини.

Од пет катрена што чине пјесму четири, и то не случајно прва четири, структурно су истовјетна: имају уоквирену структуру са подударним полукадентичним дијелом. Први стих сваког од тих четирију катрена је изосилабичан, у питању је деветерац са цезуром иза петог слога. Та четири почетна катренска стиха нису, међутим, хомолексична, него хомолексичност дијеле почетни стихови двију узастопних строфа, што значи да су на један начин хомосилабични и хомолексични почетни стихови прве двије строфе, а на други начин друге двије строфе. А та лексичка неподударност, видјећемо, врло је битна јер подразумијева тзв. пролептичку структуру почетних стихова првих двију строфа, и непролептичност тих стихова у наредне двије строфе. Разликовни елемент тог четвороструко реализованог првога стиха мезофорично је смјештен, и у питању је везнички елемент зависне изричне клаузе: у првом стиху првих двију строфа то је везник како, а у почетним стиховима друге двије строфе то је релетивна замјеница (релативизатор) који. Лексеме како и који тако диференцирају двореализацијску структуру изосилабичног и изоморфног уводнога стиха првих четирију строфа: И видех књигу како/која лети. Својеврсна прстенаста структура првих четирију строфа омогућена је истовјетним доцезурним полукадентичним четворосложним дијелом посљедњег четвртог стиха име joj je. За разлику од почетних стихова строфа, завршни стихови строфа иза тог рефренског, истовјетног полукадентичног дијела стиха не подразумијевају изосилабичност наставка стиха: у првој строфи то је четворосложна, у другој осмосложна, у трећој шестосложна, а у четвртој као и у другој осмосложна полукадентичка структура. Такав распоред такође показује да је у питању својеврсна еквивалентност која прати дводјелност задату структуром првога стиха, јер су завршени стихови парних строфа изосилабични (дванаестерци), са изометријом полукаденци, које нужно из, како ћемо видјети, кохеренцијских разлога морају бити хетеролексичне. Структурни паралелизам не огледа се само у изоморфности почетних и завршних стихова свих строфа изузев завршне, него и подударним почетним дијелом другога стиха све четири строфе, а то је акузативна предлошко-падежна замјеничка форма $y$ њьј, у улози и поетске и граматичке анафоре.

Принцип синтаксичке еквивалентности тако је темељни структурни принцип пјесме „И видех књигу” Предрага Богдановића Ција. Тај принцип посебно долази до изражаја у неримованим пјесмама, каква је и ова Богдановићева. А еквивалентност која почива на рими르 и еквивалентност заснована

${ }^{2}$ Јep, ,рима је само посебан, згуснут случај једне знатно општије - можемо чак рећи фундаменталне - појаве у поезији, наиме, паралелизма” (Јакобсон 1966: 310). 
на синтаксичком паралелизму показују „обрнут однос између улоге риме и улоге паралелизма. Тамо где рима игра велику улогу [...] улога паралелизма се смањује” (Мајенова 2009: 191). И обрнуто, улога паралелизма се појачава тамо гдје рима изостаје. Будући да ова Богдановићева пјесма није римована, улога синтаксичког паралелизма има прворазредну улогу у њеној и кохезивној и кохеренцијској структури. Уосталом, еквивалентност је најсуштаственији критеријум јакобсоновски схваћене поетске функције језика, будући да „поетска функција пројектује принцип еквивалентности из осе селекције у осу комбинације” (Јакобсон 1966: 296). Еквивалентност као структурно начело по правилу прожима и структуру пјесме у цјелини, и структуру њених строфа, али и структуре самих стихова, јер је стих „говорна јединица која је по звучној потенцији еквивалентна другим говорним јединицама истог ритмичког склопа" (Којен 1996: 6).

Све наведене и многе на њима засноване карактеристике еквивалентности готово су иманентне карактеристике пјесме „И видех књигу” Предрага Богдановића Ција, коју овдје анализирамо, полазећи од издвајања структурносемантичких карактеристика кохезивно-кохеренцијским везама „умрежених” стихова прве строфе.

Први стих пјесме - И видех књигу како лети - има структуру врло специфичне завосносложене реченице: сложене реченице са пролептичком зависном клаузом. А пролепса је стилска фигура античке реторике која подразумијева „антиципацију субјекта споредне реченице у претходној, главној реченици” (Речник 1992: 654; о тумачењима пролепсе у граматичкој и стилистичкој литератури в. исцрпно Ковачевић 1998: 169-171). Пролепсом као измјештањем реченичног члана испред зависне клаузе чијој граматичкој структури припада - граматичка се структура сложене реченице преводи у стилематичну. Постаје онеобичајена, представљајући стилистички отклон. Таква пролепса реченичну структуру чини стилски маркираном, јер мијења и граматички и семантички и стилистички статус зависносложене реченице. Претварање граматичког субјекта зависне у објекат основне клаузе остварује се у строго одређеним лексичко-синтаксичким условима. Такве реченице, наиме, за глагол основне клаузе имају по правилу неки „опсерваторни” глагол (глагол чула вида или слуха, типа: видјети, гледати, чути, слушати и сл.), а за везник зависне клаузе најчешће везник како.

Пролептичност анализиране реченице-стиха огледа се у статусу објекта къигу у структури основне клаузе, јер је тај објекат настао измјештањем граматичког субјекта зависне у позицију правог објекта основне клаузе: $И$ видех књигу како лети [ $\longleftarrow$ К видех како књига лети]. Реченица с пролептичким објектом није само стилски него и семантички „богатија” од оне непролептичке. Наиме, док је у сложеној непролептичкој реченици (реконструисаној у загради са стрелицом) зависна клауза и монофункционална и моносемична, 
јер уз глагол надређене клаузе има искључиво објекатску изричну функцију и значење (изрично значење „материјалне садржине” управног глагола), дотле је зависна клауза у пролептичкој реченици и двофункционална и бисемична. Она, наиме, није више само додатак глаголу управне клаузе него и његовом пролептичком објекту, па је изрично-атрибутска: она је изрична објекатска у односу на глагол видјети из управне клаузе, а атрибутска у односу на именицу књига у пролептичком објекту. Из тога проистиче и неподударност статуса везивног елемента како у структури пролептичке и непролептичке реченице. Везивни елемент како у непролептичкој реченици И видех како књига лети има искључиво везничку функцију, он је прави изрични везник, док је у пролептичкој конструкцији везивни елемент како нужно двофункционалан: осим што врши функцију изричног везника, он је и релативизатор (везничка ријеч), уједињујући тако у себи и значење изричног везника $\partial a$ и значење релативизатора који.

Као семантички богатије, пролептичке реченице су нужно стилистички маркиране. У наведеном стиху употреба пролептичке структуре реченице вишеструко је поетски мотивисана. Најприје, пролепсом се синтаксичко и семантичко тежиште стиха сусрећу у лексеми књига у позицији објекта. Реализовани пролептички објекат, наиме, подразумијева и граматички субјекат зависне клаузе, али не дозвољава његово експлицитно навођење (уп.: * И видех књигу како књига лети). Именица у пролептичком објекту подразумијева поред објекатске функције и значења у основној клаузи још и субјекатску функцију и значење у зависној, јер у зависној клаузи ниједном другом лексемом не може бити попуњена субјекатска позиције (уп.: *И видех књигу како птица лети). То значи да је лексема у пролептичком објекту, иако експлицитно једноструко реализована, имплицитно због структурно семантичке „задатости” двоструко присутна. Пролептички објекат том подразумијевајућом двоструком функционално-семантичком вриједношћу постаје готово идеална јединица за истицање најбитнијег дијела стиха. И управо из тих разлога Предраг Богдановић Ци посегао је за структуром пролептичке реченице у првоме стиху да би најексплицитније истакао тематски упоришну лексему цијеле пјесме, а то је лексема КњИГА.

А „књига”, чије се двоструко присуство, и поред јединачне лексичке реализације, продразумијева у првоме стиху, још двапут се анафорски преко замјеничких супститутивних конкетора реализује у првој строфи. И то на почетку другога стиха $y$ њоj [= у књизи $]$ побројане све птище и као енклитика на другоме мјесту четвртога стиха: име јоj [= књизи] је: чувар речи. Тако је „Књига” основни кохезивни елемент цијеле прве строфе: реализована је у три од њена четири стиха: у првом, другом и четвртом, док се у трећем стиху, будући да је он наставак амплификацијског низа као садржаја књиге она нужно подразумијева као „садржилац”. Ако су три стиха увезана „књигом” као 
експлицираним и деиктички израженим кохезивним стуктурним елементом, трећи стих постаје упориште кохеренцијске (смисаоне) структуре строфе. Синтаксички паралелизми су анафорског типа, а трећи стих је структурисан према амплификацијском принципу структурисања. Наиме, завршетак другога и цијели трећи стих представљају нагомилавање хомофункционалних субјеката уз пасивни предикат побројане, с тим да семантика датога глагола у предикату нужно захтијева експлицирање низа елемената које треба навести, а то су: све птице/ инсекти, рибе, биље. Пјесник је тако садржај „виђене књиге” дао кроз „побрајање” најбројнијег дијела „живог свијета”: птица, инсеката, риба и биља. Побрајајући најраспрострањеније врсте живих бића у два стиха - другом и трећем - пјесник прави својеврсно амплификативно кумулацијско ${ }^{3}$ „опкорачење”, започињући набрајање у другом стиху (све птице) и преносећи га у трећи (инсекти, рибе, биље). А тај се трећи стих не случајно завршава тачком и запетом као интерпункцијским знаком. Тачка и запета подразумијевају не само завршетак амплификацијског низа живих бића што чине садржај „виђене књиге”, него и лабавију синтаксичко-семантичку везу тог стиха са наредним. И заиста, синтаксичка ваза посљедњег стиха успоставља се са неамплификацијским дијеловима строфе, са дијеловима у којим је или експлицитно или деиктички именована књига. У завршном, четвртом, стиху прве строфе пјеснику је циљ да идентификује тип књиге, чији је садржај дат амплификацијским набрајањем живих бића у претходна два стиха. А завршни стих строфе гласи име јој је: чувар речи.

Структурно и семантички овај стих-реченица одражава структуру идентификационих реченица (о том типу реченица в. Ковачевић 2007: 95-105). То су реченице које у позицији субјекта имају деиктичку замјеницу ТО и именски предикат којим се идентификује њен садржај ${ }^{4}$ (нпр. то је инсект; то је биљка; Tо су птице; То су рибе и сл.). Субјекатски дио и копула из завршног стиха Богдановићеве пјесме функционално-семантички су еквивалентни субјекатско-копулативном дијелу идентификационе реченице (уп.: име joj je = mo je). Али нису синонимни, јер деиктичка замјеница то и субјекатска синтагма име јој (=њено име) не врше анафорску функцију на исти начин. Замјеница то може се односити или само на књигу или на амплификацијски или на цио садржај строфе, док синтагма име јој у значењу име књизи двоструко упућује на књигу, најприје посесивним енклитичким обликом датива јој као директним супститутивним замјеничким конектором $(j o j=\kappa њ и з и)$, а потом именицом име која захтијева експлицирање наслова. Уз то употреба посесивног енклитичког датива намјесто посесивног именичког датива (књизи) или посесивне замјенице (юено) уноси компоненту „симпатетитичности”, која је и иначе одлика

\footnotetext{
${ }^{3}$ О амплификативној кумулацији в. Ковачевић (2000: 360-361).

${ }^{4}$ Идентификационе реченице ,представљају језички пандан математичкој једначини (x=A)" (Клајн 2000: 79).
} 
посесивног енклитичког датива препознатљива из његове везе са етичким дативом (тип: Како си $\underline{\mathrm{mu}}$ ). Врло је значајно да је иза субјекатског дијела име joj је пјесник употријебио двотачку (име јој је:) као стилистички и прагмасемантички врло значајан интерпункцијски знак. Тим знаком се, наиме, одваја копулативни дио именског предиката (je) од предикатива као лексичког језгра предиката (чувар речи). Употреба двотачке заправо подразумијева стилистички васпостављену реторичку паузу, ради посебног наглашавања финалног елемента исказа, овдје предикатива. Предикатив наведен иза двотачке, баш захваљујући тој реторичкој паузи означеној двотачком, постаје комуникативно најзначајнија јединица цијеле строфе. У предикативу је именовањем „кондензован” цијели садржај амплификацијског дијела строфе. Друкчије речено, предикатив одражава комуникативно-поетски укус садржаја цијеле строфе. Томе посебно доприноси и чињеница да иза предикатива као краја четвртог стиха, а самим тим и завршног дијела катрена долази тачка, једина тачка у структури цијеле строфе. То значи да је, синтаксички посматрано, строфа представља стиховану обавјештајну реченицу, са више полукаденци и антикаденци и једином каденцом која се подудара с тачком обиљеженим крајем строфе. Предикативом „чувар речи” идентификује се тип књиге коју пјесник „види како лети”. Та књига набраја ријечи најразнообразнијег и најбитнијег дијела живих бића, готово свих оних што их карактерише врсност, али не и именовање њиховог јединачног примјерка. Та жива бића иманентна су и најприроднија карактеристика свијета. „Летећа књига” се тако састоји од највеће већине апелативних анимативних именица које свијет подразумијева. А управо тај дио лексике и јесте најбитнији дио свакога и свих језика свијета, а самим тим и најзначајнији дио „живога свијета” који често и упознајемо тек из и преко рјечника као „чувара речи”. Анимативни „нељудски” свијет, као да поручује пјесник, највећим дијелом упознајемо тек преко рјечника као „,увара речи”. Тако је рјечник за пјесника не само „чувар речи” него и чувар света, као извориште његовог спознавања.

Друга строфа на структурно-кохезивном плану идентична је с првом: почиње истом пролептичком реченицом као првим стихом (И видех књигу како лети), на почетку другога стиха долази деиктичка анафорска замјеница у њој (=у књизи), а четврти стих почиње истом субјекатско копулативним дијелом с двотачком (име joj je:) и у свом саставу има енклитички дативни супститутивни конектор ( цијски дио њене структуре, а то је опет амплификацијом представљен садржај књиге, чије се име открива предикативом на крају четврте строфе обиљежене тачком као знаком за каденцу. Док садржај прве књиге, како смо видјели, представља побројане врсте анимативних „нељудских” живих бића, дотле су у другој књизи коју пјесник „види како лети” забележени сви гласови, / звуци таласа, грома. У садржај друге књиге, дат амплифиакцијским набрајањем у 
другом и трећем стиху, улазе анимативно и неанимативно изазвани „звучни конституенти свијета": сви гласови живих бића, али и све ,звучеће” природне појаве што немају анимативног изазивача: звуции таласа и грома. Зато и није чудо што ту књигу пјесник у предикативу датим иза логичке посткопулативне паузе завршног стиха именује као харминија васионе („име јој је: хармонија васионе"). Пјесник очито у хармонији свијета, сагласно античкој и средњовјековној традицији, види прије свега као музички склад који чине и производе „људски глас” и „природни звукови”. Тако су звуковни елементи свемира његов најхармоничнији дио, који условљава и „хармонију људске душе”, као синегдохални израз хармоније свемира или васионе у човјеку.

Трећа строфа на структурно-кохезивном плану од прве се двије разликује само по непролептичном карактеру прве реченице-стиха. Први стих дат структурисан је не као пролептичка него као атрибутска зависна реченица. А та се разлика огледа само у везивном елементу, то више није везник како него релативна замјеница који (И видех књигу која лети). Промјена везивног елемента мијења и статус пјесниковог „виђења” и/или схватања књиге. Постојање те треће књиге не везује се само за вријеме „гледања”, њено стање није привремено, везано само за вријеме трајања „гледања” какав је случај са књигама представљеним пролептичком структуром. Наиме, И видех књигу како лети значи видим „књигу у стању летења”, док И видех кьигу која лети значи видим ,летећу књигу”. Зависном пролептичком како-клаузом заправо се не идентификује тип књиге него њено стање у времену реализације радње предиката, док се зависном који-клаузом именује тип књиге која постоји и мимо времена радње предиката. А то су књиге људи, људске књиге. Садржај те треће „књиге која лети” пјесник везује за, опет у другом и трећем стиху, амплификативно набројане истраживача свијета. Ту књигу чине речи сликара/ писаца, истраживача. То је, дакле, књига коју исписују умјетници, писци и истраживачи. То је књига свијета виђења очима умјетности и науке. Будући да је у књизи „хармионија васионе” у претходној строфи музика као хармија свемира и човјекове душе већ укључена у природну хармонију „звукова”, у овој се строфи умјетност представља сликарством као ликовном умјетношћу. Јер, музичка и ликовна умјетност јесу основни видови људске умјетности кроз историју. Насупрот њима стоје „истраживачи”, који износе научне истине о свијету. А између једних и других су писци, књижевници, који су и умјетници и научници, с тим што као и сликари и музичари дају „емоционалну” слику свијета, а будући умјетници ријечи, они с научницима дијеле ријеч као медиј обликовања „књиге”. Ту ће књигу пјесник назвати стојим пред истином („име јој је: стојим пред истином”). Неће је назвати истина, него стојим пред истином, јер коначних истина нема, нема краја умјетничком и научном представљању свијета. Нема коначне истине о свијету. „Стајати пред истином” зато значи спозна(ва)ти досадашње резултате умјетничког и научног освјетљења 
свијета, али само као степеницу на утопистичком циљу спознаје потпуне и коначне истине свијета, ка којој ће сваки онај који је, попут пјесника, „застао пред истином" нужно кренути.

Четврта је строфа по структурно-кохезивној структури еквивалентна трећој. Почиње стихом у форми сложене релативне који-реченице, други и четврти стих као и у свим претходним строфама садрже исте супститутивне анафорске конекторе ( $у$ њој и име $о \circ$ ). „Уникатни” дио у односу на трећу и претходне строфе јесте амплификацијски дат садржај књиге у неанафоричком дијелу другога стиха и цијеломе трећем стиху. Тако ће пјесник рећи да су „у њој”, у тој књизи, налазе имена свих убииа/силника, сањара рата. Ова, четврта књига, супротност је претходној: њен садржај чине рушитељи свијета, одузимачи живота, маштари ратова, уништитељи љепоте свијета. Зато у имену те књиге стоји негација највећих вриједности свијета, па се она зове невера $и$ неистина („име јој је: невера и неистина”). А нев(j)ера и неистина семантички су блиски појмови, у одређеном значењу чак и синоними. Наиме, ако именици в(j)epa поријекло потражимо у латинскоме verus, онда в(j)epa значи „истина”.

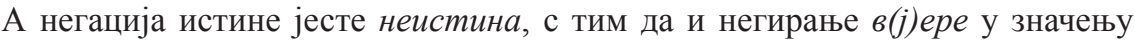
истине такође даје неистину. Тако је назив књиге невера и неистина заправо стилистички таутологичан, јер дволексички потцртава неистину не само као рушилачки порив (одређених) људи, него и као резултат њиховог дјеловања. А истина је, како смо видјели, у књизи што јој је посвећена претходна строфа представљена као умјетничка, књижевна и научна љубав према свијету. Ако је неистина супротност истини, онда је ова књига посвећена не заљубљеницима у свијет и творцима његових љепота (умјетницима, писцима и научницима), него мрзитељима и уништитељима свијета и живота (убицама, силницима и сањарима рата).

Све строфе до ове биле су посвећене свијету као слици живота. Свијету као синониму природне стварности живота. Свијету као истини живота. Прва - свијету живих бића (уз искључење људи), друга - звучној, музичкој хармонији васионе. Трећа је строфа посвећена људима, и то оним што откривају и надограђују свијет у својим дјелима, сликарским, књижевним или научним. И све су те строфе полисиндентски повезане. Први стих сваке од строфа почиње интензификаторско-везничким $u$. Прво и подразумијева да је пјесник да „виђење” прве књиге није изненадно, нејављено, случајно, оно је плод дуготрајног трагања за суштином живота, која се, ето, пред пјесником кроз књиге разоткрива. Свака строфа нова књига, свака књига упознавање дотад неспознатог дијела свијета и живота. Управо зато и сваки први стих сваке од четирију строфа што откривају четири књиге почиње надовезујућим $u$. Полисиндентској структури строфа, што низањем књига одсликава разоткривање најбитнијих „сфера” свијета и живота пјесник супротставља асиндентску структури садржаја сваке од књига. Тако су отварачки стихови 
строфа полисиндентски структурисани, а унутрашњи, мезофорични стихови, асиндентски. Или једноставније речено, књиге улазе у полисиндентски низ, а њихови садржаји у асиндентски.

Откривање књига пјесник ниже све до књиге чији садржај негира свијет и живот. До књиге „невјере и неистине”, што је друго име за мрзитеље и рушитеље свијета и живота; за оне који су људи а људима би само „о глави да раде”, који живећи у свијету за примарни циљ имају његово уништење. Зато ни низања књига више не може бити. Јер је у поље „виђења” дошла књига чији садржај чине они што су негација суштине свијета и живота. И ту је крај свему што је карактерисало претходне књиге, па самим тим и начин њиховог пјесничког представљања. Наиме, свеукупној хармонији свијета и живота пјесник је сагласио кохезивну хармонију строфа. Свака је строфа посвећена по једној „виђеној” књизи „како/која лети”. Свакој је од четирију првих строфа и појединачно и у суодносу с другим строфама синтаксички паралелизам основни конструктивни принцип, препознатљив у низу остварених еквивалентности. Најуочљивија еквивалентност тиче се изострофичности пјесме, јер су све строфе катренске. Уз то све строфе су монокадентичке, с каденцом обиљеженом тачком на крају четвртог стиха. Ништа мање није уочљив контрастни паралелизам полисиндентског представљања књига и асиндетског амплификативног представљања садржаја књига у све четири прве строфе, посматране појединачно и у суодносу. Унутарстрофична и међустрофична кохезивност стихова такође почива на паралелизму двоврсне анафоре, граматичке анафоре, с једне стране, и поетске анафоре, с друге. Граматичку анафору пјесник остварује на супститутивно-конекторски начин: замјеничким упућивањем на садржај књиге у сваком другом и четвртом стиху (замјеничким предлошко-падежним изразом у юој и енклитичким дативом име joj) првих четирију строфа. Поетска анафора подразумијева подударност почетака више стихова; а у пјесми се остварује вишеструко, јер су у све четири строфе пјесме први, други и четврти стих увијек анафорични (уп.: 1. И видех књигу... 2. у њој... 4. име јој је...), само је трећи стих неанафоричан, али преко амплификативне асиндентске кумулације остварује такође структурну еквивалентност у свакој од четирију строфа. Као што се види, хармонији свијета који „виђене” књиге откривају, сагласна је до танчина проведена структурно-кохезивна хармонија четирију строфа.

Све, међутим, престаје када пјесник „види књигу” која доноси имена рушитеља свијета и живота, књигу „невере и неистине”. Престаје и наставак низања књига, али и наставак низања еквивалентних структурно хармоничних строфа. Као да је открићем те књиге пјесник затечен. Умјесто наставка описа свијета, слиједе изрази патње због постојања и таквог (дијела) свијета. Невјерица и патња као доминантно пјесниково стање и осјећање готово да траже редупликацију израза који их изазива. Друкчије речено, као да нужно 
намећу прекид начина дотадашњег структурно-семантичког стихова и строфа. Управо због тога се тематски дио завршног стиха (име joj je) редуплицира на почетку првога и другога стиха завршне, пете, строфе: име јој је, туго, / име joj je, боле неизрециви. Тако се завршна строфа својим првим двама стиховима поетском метаформом повезује с посљедњим стихом четврте строфе. Али тај анафорички дио има улогу емоционално условљене редупликације теме. Пјесник готово да не вјерује да књига с таквим именом, што ће рећи садржајем, постоји. А несумњивост њеног постојања (п)овјереног „виђењем” код њега изазива тугу и бол. Туга и бол постају и предмет пјесничког говора и пјесникови саговорници. Пјесник први пут употребљава инвокацију ${ }^{5}$, обраћајући се властитој туги и болу, дајући их у вокативу као основној форми инвокације: име јој je, туго, / име јој је, боле неизрециви. Дајући инвокацијом властитој патњи улогу саговорника, пјесник ту патњу уопштава, представљајући је не само као властито него и као опште стање, општељудску жалост. Али није само у томе функција датих инвокација. Наиме, врло је битна разлика која прати анафорску редупликацију завршног стиха четврте строфе на почетку првих двају стихова завршне строфе. Редуплицира се тематски дио стиха име joj je, али не и двотачка. А та двотачка, нагласили смо већ, има улогу васпостављања претпредикативне реторичке паузе. А у тој позицији предикатив је комуникативно максимално наглашен и нужно јединачан. Укидањем, пак, двотачке, какав је случај у петој строфи, омогућава не само навођење више предикатива, него и њихову градацију. Синтаксички посматрано, из перспективе реченичне структуре, прва два стиха представљају субјекатско копулативни дио реченице: име joj je, док инвокативни вокатив (туго, боле неизрециви) као нереченични члан и не улази у синтаксичко-реченичну анализу. Та два стиха су, дакле, с граматичко реченичног и комуникативно реченичног становишта непотпуна - захтијевају навођење предикативног дијела реченице. А тај дио долази у трећем и четвртом стиху. Заправо трећи и четврти стих цјелином изражавају недостајући предикативни дио уз субјекатско-копулативни дио изражен првим и другим стихом, тако да би у прозу преобликовани стихови имали реченичну структуру: Име јој је, туго, боле неизрециви, заборав историје, младости, скок сриа у ништавило. Двама завршним стиховима тако су исказана три копулативна јукстапонирана (невезничка) предикатива: заборав историје, младости, / скок сриа у ништавило. Садржај тих трију предикатива стоји у климактичном градацијском односу. Јер, историју можемо знати и не знати, можемо заборавити и не заборавити, али тешко да можемо заборавити младост као симбол љепоте живота, јер бисмо се тиме одрекли и самог живота и отворили пут ка „скоку срца у ништавило”, што ће рећи укидању свих позитивних емоција које срце симболизује (љубави, прије свега), а то за

${ }_{5}^{5}$ О структурним и поетским карактеристикама инвокације в. исцрпно у Ковачевић (2006: 
крајњу посљедицу има стање ништавила као скончавања и/или нестајања и свијета и човјека у њему. А управо на такав „судњи дан” упућује књига „невере и неистине”. Из тих разлога и посљедична стања патње дата инвокативно добијају прагматички статус предикатива, тако да Име joj je, myго,/ uмe joj je,

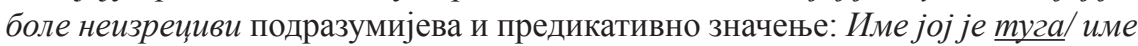
jој је бол неизрециви. То показује да на прагмасемантичком плану поетског израза и инвокативна функција вокатива може имплицирати функционалносемантичку функцију предикатива, а то онда омогућава да прави и вокативни предикативи формирају врло изнијансиран наглашено емоционалан градациони низ, будући да „невери и неистини” друго име постају и ,туга”, и „бол”, и „заборав историје”, и „заборав младости”, и „скок срца у ништавило”. А све то супротно је иманентним вриједностима свијета и живота што их подразумијеваху прве три „виђене летеће” књиге.

И да закључимо. Анализирана пјесма „И видех књигу” Предрага Богдановића Ција најексплицитније одражава суштинске карактеристике поезије уопште. Изабравши за тему књигу, Предраг Богдановић Ци је желио да покаже да се суштина и цјелина свијета једино кроз књигу могу спознати. Човјечанство историјат свог постојања прати тек развојем писменог типа језика. Тако се заправо са свијетом у цјелини и не можемо упознати без књиге, без њеног памћења. Из тих разлога код Предрага Богдановића Ција књига је заправо синоним свијету и животу. Будући да је свијет по себи хармоничан, јер космос у свом основном значењу подразумијева ред, љепоту и хармонију, Богдановић ће тој хармонији свијета сагласити хармонију пјесме. А хармонија пјесме прије свега се огледа у хармонији њене кохезивне и кохеренцијске структуре. Та структурна хармонија анализиране Богдановићеве пјесме уочљива је већ по њеној изострофичности, јер је пјесма састављена од пет структурно истовјетних - катренских - строфа. Од тих пет строфа четири прве имају изоморфну структуру, са синтаксичким паралелизмом као структурним начелом. Наиме, све строфе су монокадентичке, с каденцом обиљеженом тачком на крају четвртог стиха. Све су строфе полисидентски увезане. У тим четирима строфама, посматраним у суодносу, примијењен је контрастни паралелизам полисиндентског представљања књига и асиндетског амплификативног представљања садржаја књига. Унутарстрофична и међустрофична кохезивност стихова такође почива на паралелизму двоврсне анафоре, граматичке анафоpe, с једне стране, и поетске анафоре, с друге. Граматичку анафору пјесник остварује на супститутивно-конекторски начин: замјеничким упућивањем на садржај књиге у сваком другом и четвртом стиху (замјеничким предлошко-падежним изразом у юој и енклитичким дативом име joj) првих четирију строфа. Поетска анафора подразумијева подударност почетака више стихова; а у пјесми се остварује вишеструко, јер су у све четири строфе пјесме први, други и четврти стих увијек анафорични (уп.: 1. И видех књигу... 2. у њој... 
4. име јој је..), само је трећи стих неанафоричан, али преко амплификативне асиндентске кумулације остварује такође структурну еквивалентност у свакој од четирију строфа. Тако је хармонији свијета који „виђене” књиге откривају, сагласна до танчина реализована структурно-кохезивна хармонија четирију строфа. Завршна, пета строфа, са претходним дијели само катренску вриједност. Све остало и на кохезивном и на кохеренцијском плану разликује је од претходних строфа. Наиме, када у четвртој строфи пјесник „види књигу” која доноси имена рушитеља свијета и живота, књигу „невере и неистине”, престаје и наставак низања књига, али и наставак низања еквивалентних структурно хармоничних строфа. Као да је открићем те књиге пјесник затечен. Пета строфа само показује „лице и наличје” оних што су садржај књиге „невере и неистине”. За разлику од претходних строфа што представљају дескрипцију „виђених књига”, завршна строфа исказује пјесникову патњу, представљену на поетски врло специфичан начин наглашено емоционалним градациони низ предикатива, будући да „невери и неистини” друго име постају и „туга”, и „бол”, и „заборав историје”, и „заборав младости”, и „скок срца у ништавило". Тако се код Богдановића човјек јавља и највећом вриједности и највећом опасности свијета, он је као „истина” потврда хармоније свијета, а као „невера и неистина" рушитељ и мрзитељ суштинских вриједности свијета и живота.

\section{ИЗВОР}

Предраг Богдановић Ци, „И видех књигу”, Трубе и печати, Београд, Рашка школа, 2010, 23.

\section{ЛИТЕРАТУРА}

Јакобсон 1966: Roman Jakobson, Lingvistika i poetika, Beograd: Nolit.

Клајн 2000: Иван Клајн, Лингвистичке студије, Београд: Партенон.

Којен 1996: Леон Којен, Студије о српском стиху, Сремски Карловци, Нови Сад: Издавачка књижарница Зорана Стојановића.

Ковачевић 1998: Милош Ковачевић, „Сложена реченица с пролептичким објектом”, Синтакса сложене реченице у српском језику, Београд: Рашка школа, 169-180.

Ковачевић 2000: Милош Ковачевић, Стилистика и граматика стилских фигура, Крагујевац: Кантакузин. 
Ковачевић 2006: Милош Ковачевић, „Инвокација и апострофа у Шантићевој поезији”, Списи о стилу и језику, Бањалука: Књижевна задруга, 96-125.

Ковачевић 2007: Милош Ковачевић, „О једној специфичној синтаксичко-семантичкој употреби лексеме ТО”, Србистичке теме, Крагујевац: ФИЛУМ, 95-105.

Мајенова 2009: Marija Renata Majenova, Teorijska poetika, prevod s poljskog Biserka Rajčić, Beograd: Službeni glasnik.

Радовић 2010: Миодраг М. Радовић, „Предраг Богдановић - Ци и питање књиге”, поговор књизи: Предраг Богдановић Ци, Трубе и печати, Београд: Рашка школа, 119-125.

Ракитић 2010: Слободан Ракитић, „Суштине и не-суштине у трагању за књигом живота и смрти”, предговор књизи: Предраг Богдановић Ци, Трубе и печати, Београд: Рашка школа, 9-17.

Речник 1992: Речник књижевних термина, уредник Драгиша Живковић, Београд: Нолит.

\section{STYLISTIC PATHS THROUGH PREDRAG BOGDANOVIĆ CI'S POEM OF THE BOOK OF THE WORLD}

\section{Summary}

The paper furnishes a detailed linguostylistic analysis of the poem "And I Beheld a Book" by Predrag Bogdanović Ci. The mentioned poem best demonstrates how and why the "book" is the fundamental topic of Bogdanović's poetry. To Predrag Bogdanović Ci, the book is a synonym of the world and life. As the world is harmonic by itself, since the universe in its basic meaning implies order, beauty and harmony, Bogdanović will attune the harmony of the world to the harmony of the poem. First and foremost, the harmony of the poem is reflected in the harmony of its cohesive and coherent structure. This poem by Bogdanović is structured on diverse specifically "networked" cohesive and coherent relations: isostrophe, combination of grammatical and poetic anaphor, amplification, polysyndetic and asyndetic coordination, etc. All this indicates that in the analysed poem by Predrag Bogdanović Ci, the (dis)harmony of the world revealed by the "beheld" books is attuned to the structural-cohesive (dis)harmony of the stanzas, seen individually and in interrelation.

Keywords: Predrag Bogdanović Ci, book, harmony of the world, harmony of the poem, parallelism, cohesion, coherence 